Experiments on the use of mineral oil adjuvants and aluminium phosphate as an adjuvant showed little promise, although aluminium phosphate may be of value for concentrating and purifying antigen.

We are indebted to the following for help with this work: Dr. K. Fantes (Glaxo Group Limited) for adsorbing rhinoviruses on to aluminium phosphate gel; Dr. F. Himmelweit for supplying Drakeol-Arlacel; Mr. P. D. McHugh and Miss A. MacIntyre (Pfizer Ltd.) for carrying out neutralization tests on volunteers given Pfizer H.G.P. vaccine; Dr. M. L. Bynoe and Miss E. Bullock (Common Cold Research Unit) for clinical observations; and technicians for their excellent assistance. We would also like to thank volunteers at the Common Cold Research Unit, at the Microbiological Research Establishment, Porton, and at Salisbury Theological College, and the general practitioners who administered vaccine.
REFERENCES

Andrewes, C. H. (1948). F. roy. Soc. Arts, 96, 200.
Buckland, F. E., Doggett, J. E., and Tyrrell, D. A. J. (1964) F. Hyg. (Lond.), 62, 115 .

Byna and Tyrrell, D. A. J. (1965). Ibid. In press. Bynoe, M. L., Hobson, D., Horner, J., Kipps, A., Schild, G. C., and Doggett, J. E., Bynoe, M. L., and Tyrrell, D. A. J. (1963). Brit. med.

Fantes, K. H. (1962). F. Hyg. (Lond.), 60, 123.

Hamre, D., and Procknow, J. J. (1963). Amer. Rev. resp. Dis., 88, Part 2, p. 277.

Hayflick, L., and Moorhead, P. S. (1961). Exp. Cell. Res., 25, 585.

Himmelweit, F. (1960). Brit. med. 7., 2, 1690.

Mogabgab, W. J. (1962). Amer. F. Hyg., 76, 15

Mufson, M. A., Ludwig, W. M., James, H. D., Gauld, L. W., Rourke, J. A., Holper, J. C., and Chanock R. M.' (1963). J. Amer. med. Ass., 186, 578.

Price, W. H. (1957). Proc. nat. Acad. Sci. (Wash.), 43, 790.

Taylor-Robinson, D. (1963). Arch. ges. Virusforsch., 13, 281.

Tyd Tyrrell, D. A. J. (1962). Brit. F. exp. Path., 43, 264.

Tyrrell, D. A. J., Bynoe, M. L., Buckland, F. E., and Hayflick, L. (1962). and Parsons, R. (1960). Ibid., 1, 239.

\title{
Treatment of Acute Haematogenous Osteitis in Children Assessed in a Consecutive Series of Selected Cases
}

\author{
GERALD A. NELIGAN,* D.M., M.R.C.P.; F. MICHAEL ELDERKIN, $†$ M.B., M.R.C.P.ED., D.C.H.
}

Brit. med. F., 1965, 1, 1347-1350

Widespread lack of agreement about the correct treatment of a relatively common disease may be due to comparable lack of agreement about the clinical definitions and the standards of comparison which should be used in studying the problem. Disagreement about the correct treatment of acute haematogenous osteitis in children is both widespread and chronic. Its most recent overt manifestation was in the correspondence which followed the article by Harris (1962) in which he advocated early surgical drainage, including drilling to "decompress" the bone, as the one sure way of preventing the complication of a "chronic infection with a discharging sinus or obvious sequestrum formation." In the subsequent correspondence, equally strong conviction appeared to support every variety of advice, from the statement that "the only rational procedure is to "deroof 'the cavity and scoop out the debris" (Subrahmanyan, 1962), through a variety of equally emphatic statements concerning the proper place of antibiotics, surgical drainage, aspiration, and splintage, to the pronouncement by Pappworth (1962) that "the treatment of acute osteomyelitis is not surgery but the correct use of antibiotics."

The seriousness of the situation brought about by this state of confusion and lack of clear purpose is illustrated by the startling incidence of complications (as defined above) reported during the past few years- $31 \%$ by Harris (1962), $28 \%$ by Mann (1963), and $31 \%$ of the cases treated by operative decompression by Gilmour (1962). The declared purpose of Mann's (1963) paper was to oppóse early surgical drainage and to support the view that "the proper treatment of acute osteitis depends upon early diagnosis and prompt initiation of full treatment, including rest, splintage, and correct antibiotic therapy" (in that order).

The lack of agreement about clinical definitions and standards of comparison, which has led to such widespread disagreement about treatment, is rather less obvious, perhaps, but can be illustrated by reference to the last three papers quoted. Harris

\footnotetext{
* Senior Lecturer in Child Health, University of Newcastle upon Tyne. t Late Senior Registrar, Department of Child Health, Royal Victoria Infirmary, Newcastle upon Tyne.
}

(1962) implied that there was some virtue in the fact that his 84 patients were " unselected." But the truth is that, in such a disease as this, failure to select cases for study implies failure to allow for the many definable factors which may affect the outcome and which "all summate to make each case unique" (Mann, 1963). "Unselected" cases of this disease cannot usefully be compared with each other. Moreover, it is strange to find that of the five cases which Harris describes in a paper whose title referred to the " early stages of acute osteomyelitis," one was admitted 28 days after the onset, in another the essential surgical intervention was delayed for 17 days, and in a third no effective antibiotic treatment was given for the first 19 days. The clinical definitions used by Mann (1963) are equally open to question. Of the 59 cases which he included, the clinical diagnosis was supported by radiological evidence " in most patients"-but by no confirmatory evidence in the remainder. Purely clinical evidence is, of course, all that should be available, or necessary, for the clinical purpose of initiating treatment: but such evidence alone is inadequate for the scientific purpose of determining the results of treatment (Trueta and Morgan, 1954). Reliance upon this sort of evidence may explain Mann's (1963) statement that "some are treated satisfactorily at home." We do not know of any such case in which the diagnosis was based upon acceptable evidence: and one need look no further than his own Case 1 to see the disastrous consequences which may result from a policy based on such a statement. But our main criticism concerns his sweeping condemnation of all studies of this disease which " tend to be statistical," on the ground that no group of cases is "homogeneous." This seems all the more surprising since he listed a number of factors likely to affect the outcome, which could (if properly defined) have been used to select a series of cases suitable for comparative studies. Gilmour (1962) went so far as to stress the importance of dividing cases into three grades of severity (mild, moderate, and severe) before analysing the results of treatment in any series, but did not define his grades of severity or apply his advice to the analysis of his own series. He also dismissed the question of delay in admission to hospital as having no effect upon the outcome. 
We believe that in the case of acute osteitis, as of any other disease, proper selection of a consecutive series of comparable cases for study is the only way to resolve the sort of disagreement about treatment which we have illustrated. The special problem in the case of osteitis is that, because of the unusually large number of definable factors which may influence the prognosis, the process of selection has to be unusually rigorous.

These principles underlay the planning of the study carried out by Bremner, Neligan, and Warrick (1954), which was designed to use a precise method of measurement for comparing the results obtained by two different techniques of surgical treatment. The cases analysed were selected in accordance with criteria which ensured that they were truly comparable with each other by the method of measurement used, and that they provided a true test of surgical technique (we excluded cases admitted so early that antibiotic treatment nlone was likely to produce a complete cure). We found that, provided subperiosteal pus was removed as soon as possible, it made no measurable difference whether this was done by aspiration through a wide-bore needle or by open operation with drilling of the bone.

\section{Present Series}

Our aim in the present investigation was to determine, and illustrate, the results which may be expected if reasonably early diagnosis and admission to hospital make it possible to treat a consecutive series of comparable cases of acute osteitis in accordance with the two cardinal principles of modern treatment of any severe pyogenic infection-namely, to start treatment with a fully effective antibiotic in effective dosage before irreparable damage has occurred, continuing until there is evidence that the infection has been eliminated, and to remove any significant collection of pus as soon as it can be detected or suspected.

\section{Selection of Cases}

Our criteria for selection of cases were suitably modified from those used by Bremner et al. (1954). Because we are no longer interested in the narrow (and long since resolved) argument about surgical technique, we have included cases admitted within 48 hours after the onset of pain. Because the penicillinresistant staphylococus is nowadays relatively common, we have included cases due to such organisms. The criteria for inclusion in our present series, which we have applied retrospectively to all the acceptable cases of acute osteitis admitted to the children's wards of this hospital between February 1957 and January 1954, are as follows:

Age: 2-14 years.

Grade: Severe, by the same clinical definition as was outlined by Bremner et al. (1954) and described in greater detail by Bremner and Neligan (1958)-namely, that all the essential

\begin{tabular}{|c|c|c|c|c|c|c|c|c|c|c|c|c|c|}
\hline \multirow{2}{*}{$\begin{array}{l}\text { Case } \\
\text { No. }\end{array}$} & \multirow{2}{*}{$\begin{array}{c}\text { Age } \\
\text { (Years) }\end{array}$} & \multirow{2}{*}{\multicolumn{2}{|c|}{ Bone }} & \multirow{2}{*}{$\begin{array}{l}\text { Duration } \\
\text { (Hours) }\end{array}$} & \multicolumn{2}{|c|}{ Staph. aureus } & \multicolumn{2}{|c|}{ Antibiotic } & \multirow{2}{*}{$\begin{array}{c}\text { Aspiration } \\
\text { Volume (ml.) }\end{array}$} & \multirow{2}{*}{$\begin{array}{c}\text { Full } \\
\text { (Dctivity } \\
\text { (Days) }\end{array}$} & \multicolumn{2}{|c|}{ Follow-up } & \multirow{2}{*}{ Comments } \\
\hline & & & & & Blood & Pus & Drug & Days & & & $\begin{array}{l}\text { Duration } \\
\text { (Months) }\end{array}$ & $X$-ray & \\
\hline 1 & 14 & Tibia & $\downarrow$ & 65 & $\mathbf{S}$ & $\mathbf{S}$ & Pen. & 27 & 5,6 & 27 & 91 & Normal & \\
\hline 2 & 4 & Tibia & $\uparrow$ & 168 & $\mathbf{R}$ & $\mathbf{R}$ & $\begin{array}{l}\text { Tetra. } \\
\text { Erythro. }\end{array}$ & $21\} 35$ & 5 & 35 & 91 & " & \\
\hline 3 & 6 & Femur & 1 & 54 & $\mathbf{R}$ & $\mathbf{R}$ & Tetra. & 35 & 20,4 & 200 & 84 & $"$ & $\begin{array}{l}\text { Sequestrectomy } \\
5 / 12 \text { after onset }\end{array}$ \\
\hline $\begin{array}{l}4 \\
5\end{array}$ & $\begin{array}{l}8 \\
8\end{array}$ & $\begin{array}{l}\text { Ulna } \\
\text { Femur }\end{array}$ & $\downarrow$ & $\begin{array}{l}120 \\
125\end{array}$ & $\mathbf{R}$ & $\underset{\mathbf{R}}{\mathbf{S}}$ & $\begin{array}{l}\text { Pen. } \\
\text { Tetra. }\end{array}$ & $\begin{array}{l}21 \\
26\end{array}$ & $\begin{array}{l}2 \\
30\end{array}$ & $\begin{array}{l}49 \\
34\end{array}$ & $\begin{array}{l}85 \\
82\end{array}$ & $"$ & \\
\hline 6 & 5 & Femur & $\downarrow$ & 32 & & & $\begin{array}{l}\text { Pen. } \\
\text { Tetra }\end{array}$ & 19 & & 21 & 82 & " & \\
\hline $\begin{array}{r}7 \\
8 \\
9 \\
10 \\
11\end{array}$ & $\begin{array}{r}11 \\
12 \\
5 \\
3 \\
7\end{array}$ & $\begin{array}{l}\text { Tibia } \\
\text { Femur } \\
\text { Tibia } \\
\text { Femur } \\
\text { Tibia }\end{array}$ & $\downarrow$ & $\begin{array}{r}144 \\
53 \\
32 \\
116 \\
90\end{array}$ & $S$ & $\begin{array}{l}\mathbf{S} \\
\mathbf{S} \\
\mathbf{S} \\
\mathbf{S} \\
\mathbf{S}\end{array}$ & $\begin{array}{l}\text { Pen. } \\
\text { Pen. } \\
\text { Pen. } \\
\text { Pen. } \\
\text { Pen. } \\
\text { Pen. }\end{array}$ & $\begin{array}{l}49 \\
28 \\
23 \\
31 \\
35\end{array}$ & $\begin{array}{l}++ \\
5 \\
0.5 \\
++ \\
++\end{array}$ & $\begin{array}{l}49 \\
30 \\
23 \\
31 \\
43\end{array}$ & $\begin{array}{l}82 \\
80 \\
78 \\
73 \\
72\end{array}$ & $\begin{array}{l}\text { "' } \\
\text { ", } \\
\text { ", }\end{array}$ & \\
\hline 12 & 12 & Femur & $\uparrow$ & 32 & $\mathbf{S}$ & & $\begin{array}{l}\text { Pen. } \\
\text { Tetra. }\end{array}$ & 23 & & 23 & 69 & $\eta$ & \\
\hline 13 & 11 & Femur & 1 & 72 & $\mathbf{S}$ & $\mathbf{S}$ & Pen. & 28 & 30 & 28 & 68 & $\begin{array}{l}\text { Slight corti- } \\
\text { cal thicken- } \\
\text { ing }\end{array}$ & \\
\hline 14 & 13 & Tibia & $i$ & 168 & $\mathbf{S}$ & $\mathbf{S}$ & Pen. & 41 & 3 & 35 & 67 & Normal & \\
\hline 15 & 12 & Tibia & $\downarrow$ & 50 & & & $\begin{array}{l}\text { Pen. } \\
\text { Tetra. }\end{array}$ & 21 & & 33 & 67 & ," & \\
\hline 16 & 13 & Femur & $\downarrow$ & 120 & $S$ & & Pen. & 56 & & 70 & 66 & Co"̈rical & \\
\hline 17 & 2 & Femur & $\downarrow \uparrow$ & 48 & $\mathbf{R}$ & $\mathbf{R}$ & Pen. $\}$ & 270 & $\begin{array}{c}25,5,10,50 \\
60,25,30\end{array}$ & 180 & 65 & $\begin{array}{l}\text { Cortical } \\
\text { thickening }\end{array}$ & $\begin{array}{r}\text { Sequestrectomy } 3 \\
\text { years after onset }\end{array}$ \\
\hline 18 & 4 & Radius & 1 & 72 & & & $\begin{array}{ll}\text { Pen. } & \\
\text { Tetra } & \end{array}$ & 21 & & 21 & 63 & Normal & \\
\hline 19 & 12 & Humerus & $\uparrow$ & 96 & $\mathbf{R}$ & $\mathbf{R}$ & $\begin{array}{l}\text { Pen. } \\
\text { Tetra. }\end{array}$ & 48 & & 84 & 62 & $"$ & \\
\hline 20 & 11 & Femur & $\downarrow$ & 96 & & & $\begin{array}{l}\text { Pen. } \\
\text { Tetra }\end{array}$ & 32 & & 63 & 61 & " & \\
\hline 21 & 5 & Femur & $\downarrow$ & 90 & & $\mathrm{~S}$ & Pen. & 42 & 2 & 42 & 60 & $\begin{array}{l}\text { Slight } \\
\text { cortical } \\
\text { thickening }\end{array}$ & \\
\hline 22 & 9 & $\begin{array}{l}\text { Fibula } \\
\text { Tibia }\end{array}$ & $\downarrow$ & 53 & $\mathbf{S}$ & $\stackrel{S}{S}$ & Pen. & 44 & $\begin{array}{l}3 \\
9 \\
25\end{array}$ & 52 & 53 & $\begin{array}{l}\text { Normal } \\
\text {,y }\end{array}$ & \\
\hline 23 & 4 & Humerus & $\uparrow$ & 130 & $\mathbf{R}$ & $\mathbf{R}$ & $\begin{array}{l}\text { Pen. } \\
\text { Tetra. }\end{array}$ & 87 & 35,35 & 126 & 53 & " & \\
\hline $\begin{array}{l}24 \\
25 \\
26\end{array}$ & $\begin{array}{r}12 \\
13 \\
3\end{array}$ & $\begin{array}{l}\text { Tibia } \\
\text { Femur } \\
\text { Femur }\end{array}$ & $\downarrow$ & $\begin{array}{r}66 \\
144 \\
48\end{array}$ & $\stackrel{S}{S}$ & $\begin{array}{l}S \\
S \\
S\end{array}$ & $\begin{array}{l}\text { Pen. } \\
\text { Pen. } \\
\text { Pen. }\end{array}$ & $\begin{array}{l}58 \\
59 \\
21\end{array}$ & $\begin{array}{l}4,15,4 \\
25 \\
5\end{array}$ & $\begin{array}{l}63 \\
45 \\
13\end{array}$ & $\begin{array}{l}52 \\
44 \\
39\end{array}$ & $\begin{array}{c}\text { Normal } \\
, "\end{array}$ & \\
\hline 27 & 6 & Tibia & $\uparrow$ & 29 & & & Ten. & 30 & & 27 & 37 & " & \\
\hline $\begin{array}{l}28 \\
29\end{array}$ & $\begin{array}{r}10 \\
7\end{array}$ & $\begin{array}{l}\text { Fibula } \\
\text { Tibia }\end{array}$ & $\uparrow$ & $\begin{array}{r}130 \\
96\end{array}$ & & $\mathbf{S}$ & $\begin{array}{l}\text { Meth. } \\
\text { Pen. }\end{array}$ & $\begin{array}{l}32 \\
34\end{array}$ & 8 & $\begin{array}{l}32 \\
32\end{array}$ & $\begin{array}{l}35 \\
35\end{array}$ & $\begin{array}{l}\text { Slight } \\
\text { cortical } \\
\text { thickening }\end{array}$ & \\
\hline $\begin{array}{l}30 \\
31 \\
32 \\
33 \\
34 \\
35 \\
36 \\
37\end{array}$ & $\begin{array}{r}2 \\
9 \\
12 \\
9 \\
9 \\
12 \\
11 \\
10\end{array}$ & $\begin{array}{l}\text { Fibula } \\
\text { Femur } \\
\text { Tibia } \\
\text { Tibia } \\
\text { Tibia } \\
\text { Femur } \\
\text { Femur } \\
\text { Femur }\end{array}$ & $\begin{array}{l}1 \\
1 \\
1 \\
\downarrow\end{array}$ & $\begin{array}{r}22 \\
54 \\
168 \\
55 \\
32 \\
168 \\
48 \\
168\end{array}$ & $\begin{array}{l}\mathbf{S} \\
\mathbf{R} \\
\mathbf{S} \\
\mathbf{R} \\
\mathrm{S}\end{array}$ & $\begin{array}{l}S \\
S \\
R \\
S \\
S\end{array}$ & $\begin{array}{l}\text { Pen. } \\
\text { Meth. } \\
\text { Pen. } \\
\text { Pen. } \\
\text { Clox. } \\
\text { Pen. } \\
\text { Pen. } \\
\text { Pen. }\end{array}$ & $\begin{array}{r}25 \\
26 \\
126 \\
37 \\
56 \\
63 \\
29 \\
85\end{array}$ & $\begin{array}{l}50,20 \\
8,12 \\
16 \\
30 \\
40,30\end{array}$ & $\begin{array}{l}25 \\
26 \\
91 \\
37 \\
82 \\
63 \\
29 \\
85\end{array}$ & $\begin{array}{l}35 \\
35 \\
21 \\
20 \\
19 \\
18 \\
12 \\
12\end{array}$ & $\begin{array}{c}\text { Normal } \\
\text { ", } \\
\text { ", } \\
\text { ", } \\
\text { ", } \\
\text { Patchy } \\
\text { sclerosis }\end{array}$ & \\
\hline 38 & 13 & Tibia & $\downarrow$ & 51 & & $\mathbf{S}$ & Pen. & 22 & $0.5^{*}$ & 22 & 13 & Normal & \\
\hline
\end{tabular}


clinical symptoms were fully developed within 72 hours of the start of the pain.

Duration on admission: 0-168 hours.

Bone involved : Major long bone of a limb.

Joints: Free of infection on admission.

The clinical diagnosis was supported by confirmatory radiological changes in all cases except one, where the organisms were recovered from the affected metaphysis through a marrow-puncture needle. Thirty-eight cases complied with all these criteria.

\section{Treatment}

The details of the treatment, carried out by the clinicians under whose care the children happened to be admitted, were as follows:

(a) Antibiotic treatment was started as soon as possible-namely, as soon as the clinical diagnosis had been made by an experienced observer and blood had been taken for culture. Initial treatment was with a combination of penicillin $G$ and chlortetracycline from 1957 to 1961, and with methicillin or cloxacillin since then. In either case a change was made to penicillin $G$ alone if indicated by the results of sensitivity tests on any organism recovered from the lesion or the blood; otherwise the appropriate antibiotic or combination was continued. Daily dosage was always twice as great as for a soft-tissue infection: administration was by three-hourly intramuscular injection until humane modification of this regime to six-hourly injection, or even to oral administration in the case of cloxacillin, was justified by a favourable clinical response (usually after about a week). This treatment was continued for a minimum of three weeks, or until the weekly erythrocyte sedimentation rate had fallen to $20 \mathrm{~mm}$. in one hour or thereabouts.

(b) Any pus which formed in the subperiosteal space was aspirated or expressed through a wide-bore needle under general anaesthesia. The indication for the initial aspiration was extension of the bone tenderness well beyond the metaphysis (Bremner et al., 1954); if it had to be repeated after some days, the indication was usually given by more classical signs of the presence of pus, since this was no longer confined deep to the periosteum but could escape through the holes made by the needle the first time. The initial aspiration was performed as soon as possible after the indication arose, with the proviso that no local intervention was carried out until some hours after the start of the presumably effective antibiotic treatment.

Splinting was used in only five cases, when the indication was that it could ease the pain or immobilize a joint suspected to be infected: it was given up as soon as the indication disappeared, usually after a few days. In the four cases where the lesion was near the hip-joint, free skin traction with a weight and pulley was used until all signs of muscle spasm had cleared. The decision to allow resumption of normal use of the limb was made in accordance with the radiological criteria described by Neligan and Warrick (1953).

Brief details of each case are given in the Table. They may be summarized as follows.

\section{Cases in Brief}

Clinical Features.-The bones involved were the femur in 16 cases (in 4 of which the lesion was at the upper end), the tibia in 15 , humerus in 2, fibula alone in 2, femur and fibula in 1 , the radius in 1 , and ulna in 1 . The mean length of the history from start of the pain until the time of admission was 90 hours. A Staphylococcus aureus was recovered from 32 cases (from the lesion alone in 12 cases, from the blood alone in 5 , and from both in 15 cases) ; 8 (25\%) of the 32 strains were resistant to penicillin, but none to tetracycline or to the synthetic penicillins since they became available.

Treatment.-The antibiotic used after the initial phase was penicillin $G$ alone in 23 cases, and in combination with chlortetracycline in 9 ; chlortetracycline alone in 2 cases, and in combination with erythromycin in 1 case ; a synthetic penicillin alone in 3. The mean duration of antibiotic treatment in the
36 uncomplicated cases was 33 days for those admitted within 96 hours, and 54 days for those admitted later. Aspiration of subperiosteal pus was never indicated in 13 cases ; it was carried out once in 17 cases, twice in 6 , three times in 1 , and no fewer than seven times in $1 .^{1}$ Only two of the seven cases admitted within the first 48 hours required a single aspiration. In Case 38 the affected metaphysis was aspirated through a marrowpuncture needle to obtain the organism for culture and sensitivity-testing.

Results.-Two cases ( $5 \%$ ) developed a complication, as defined. In both (Cases 3 and 17) the lesion was in the lower femur, caused by a penicillin-resistant organism which was treated with chlortetracycline with or without penicillin in the days before a synthetic penicillin was available. Both were admitted to hospital quite promptly (48 and 54 hours after the onset), and in both cases a sequestrum had eventually to be removed by open operation. The remaining 36 cases were clinically cured by the time their initial course of antibiotics was stopped; they were able to resume normal activity after a mean of 32 days if admitted within the first 96 hours, and 68 days if admitted between 96 hours and 168 hours after the onset.

Follow-up.-The mean period for which cases have been followed so far is 52 months (range one to seven and a half years). Of the 36 uncomplicated cases, 32 have normal radiographs, in three there is residual cortical thickening or widening but they are progressing steadily towards normality, and in one there is residual patchy sclerosis 10 months after resumption of full activity. Of the two complicated cases, one has a normal radiograph seven years after the sequestrectomy, and the other's cortex is still sclerotic and thickened after two and a half years. Both are clinically normal apart from the sequestrectomy scars.

\section{Conclusions}

Our findings confirm that, even in cases of severe acute osteitis of major long bones occurring at a period when a worrying proportion of such infections are caused by a penicillin-resistant staphylococcus, the complication rate need be no higher than that reported by Trueta and Morgan (1954). Their complication rate of $5 \%$ sequestrum formation and $12 \%$ "scaling of the bone" followed routine use of open operation, with drilling of the bone, in an unselected series of cases at a time before penicillin-resistance had become a problem. Our similar rate of sequestrum formation followed routine use of aspiration in a selected series of severe cases involving major long bones. These results confirm the findings of Bremner et al. (1954) that it makes no measurable difference which technique is used for removing subperiosteal pus.

There is a strong suggestion in our two complicated cases that the bacteriostatic drug tetracycline is less effective than penicillin (whether natural or synthetic). This might explain the rather alarming statements of Gilmour (1962) concerning the enhanced virulence of staphylococci in Western Australia after 1950, when a very high proportion of the organisms were penicillin-resistant. Undoubtedly, in these days of increasing incidence of penicillinase-producing strains, the antibiotic of choice for initial treatment is methicillin or cloxacillin.

Splintage is unnecessary in the acute stage except for the very limited (and transient) indications mentioned. There are a few cases, of which one occurred in this series (Case 17), where such rarefaction of the bone may develop after two months or so that a pathological fracture is feared, when a plaster cast or splint may have to be used until recalcification is evident (Neligan and Warrick, 1953).

The crux of the whole matter appears to us to be the speed with which the diagnosis is made and the child admitted to

\footnotetext{
${ }^{1}$ Case 17 (see Table), due to a penicillin-resistant organism, and treated with chlortetracycline. The need for more than two aspirations strongly suggests that the antibiotic is not fully effective.
} 
hospital. This issue can be obscured by the occasional mild case-commoner in younger children and smaller bones, as described by Bremner and Neligan (1958)-in which delay in terms of days or even weeks may be relatively harmless. In the much commoner severe cases in older children the target period for admission is the first 48 hours after the start of the pain. Then an effective antibiotic will produce a complete cure without any need for local intervention in about $90 \%$ of cases (present series plus 41 such cases reported by Bremner and Neligan in 1958). Even up to 96 hours after the onset a relatively short course of antibiotic treatment, usually supplemented by removal of pus, will result in a relatively quick return to full activity. We know that in three-quarters of cases the family doctor has seen the patient within the first of these target periods, and in almost all within the second.

When there is delay in diagnosis we have evidence (Bremner and Neligan, 1958) that the commonest cause is the doctor's failure to appreciate that there is both a systemic illness and a local lesion in a bone, near but not in a joint, giving rise to the diagnostic sign of " one-finger tenderness." Any suspicion of osteitis should be the indication for immediate referral to hospital. The diagnosis may often be difficult, and should be confirmed by the most experienced observer available; only in hospital can the fullest possible bacteriological information and the most effective regime of antibiotic administration be made available, and local surgical intervention may become necessary at any time. It matters little to whom the case is referred, so long as all those who may be primarily concerned in the casualty, paediatric, and orthopaedic departments are fully alert to the requirements of diagnosis and treatment, and ready to call for help when required. In view of the nature of the disease some form of collaboration between orthopaedic surgeon and paediatrician seems desirable (Annan and Sweetnam, 1962).

We believe that such collaboration, in support of effective action by the family doctors, who are the first to see these patients, can still produce satisfactory results in the great majority in spite of the emergence of penicillin-resistant organisms. The results of the present investigation support this view and underline the importance of immediate referral to hospital, followed by purposeful use of the most effective antibiotics currently available, and prompt removal of any pus which forms in the subperiosteal space.

\section{Summary}

Reference to the recent literature on the subject suggests that there is widespread disagreement about the correct treatment of acute osteitis in children, and that the incidence of unsatisfactory results is about $30 \%$. Both these very disturbing findings appear to be attributable to the dearth of planned studies of suitably selected cases.

We report the findings of a retrospective study of the methods and results of treatment in a consecutive series of 38 cases of severe acute osteitis in older children admitted to hospital during 1957-63, and selected in accordance with defined clinical criteria. Effective antibiotic treatment was started as soon as possible, and pus which formed in the subperiosteal space was removed (by aspiration) as soon as the indication arose. Results were satisfactory in $95 \%$ of cases ; the two unsatisfactory cases in which sequestra formed were caused by penicillin-resistant organisms treated with chlortetracycline. It seems likely that the use of methicillin or cloxacillin in such cases should reduce the incidence of unsatisfactory results.

The importance of achieving the earliest possible diagnosis and admission to hospital is illustrated by reference to the higher incidence of operative intervention if effective treatment is delayed till after the first 48 hours, and the longer duration both of antibiotic treatment and of disability in cases admitted after the first 96 hours.

We would like to thank our colleagues, under whose care the patients were admitted, for permission to report these cases, and particularly Mr. A. E. Bremner who performed the two sequestrectomies.

\section{REFERENCES}

Annan, J. H., and Sweetnam, W. P. (1962). Brit. med. F., 1, 1693. Bremner, A.' E., and Neligan, G. A. (1958). Chapter on "Pyogenic Osteitis" in Recent Advances in Paediatrics, 2nd ed., edited by D. M. T. Gairdner. Churchill, London. D. M. T. Gairdner. Churchill, London.

Gilmour, W. N. (1962). f. Bone ft Surg., 44B, 841.

Harris, N. H. (1962). Brit. med. f., 1, 1440.

Mann, T. S. (1963). Ibid., 2, 1561.

Neligan, G. A., and Warrick, C. K. (1953). F. Fac. Radiol. (Lond.), 5, 112.

Pappworth, S. (1962). Brit. med. f., 2, 338.

Trueta, J., and Morgan, J. D. (1954). Brit. F. Surg., 41, 449.

\footnotetext{
* Research Associate, Fairleigh-Dickinson University, Madison, New Jersey.

† Supervising Biochemist, Atherosclerosis Research Group, St. Vincent's Hospital, Montclair, New Jersey.

$\ddagger$ Director, Atherosclerosis Research Group, St. Vincent's Hospital, Montclair, New Jersey.
}

Studies on the influence of calcium in the digestion of lipids were not restricted to man. A similar effect with long-chain triglycerides and hydrogenated fats was found in rats (Cheng et al., 1949 ; Carroll and Richards, 1958), cattle (Ward and Reid, 1948), chickens (Fedde et al., 1960), and dogs (Steudel, 1944, 1947).

Since calcium has been reported to decrease lipid absorption, it was of interest to determine the effect of this alteration upon human serum lipids. This is a preliminary report of a study to assess the effects of ingested supplemental calcium upon serum lipids, including cholesterol, triglycerides, and phospholipids. 